\title{
Het gebruik van Engels als voertaal in het medisch onderwijs
}

\author{
R. Dijcks, D.H.J.M. Dolmans, J.F.C. Glatz
}

\section{Samenvatting}

Inleiding: Het gebruik van Engels als voertaal in drie blokken in het vierde studiejaar van de Maastrichtse opleiding geneeskunde heeft enerzijds tot doel eigen studenten de mogelijkheid te bieden medisch Engels te oefenen en anderzijds deelname van buitenlandse studenten aan het onderwijsprogramma mogelijk te maken.

Methode: Vanaf de invoering van de Engelstalige blokken is systematisch geëvalueerd hoe de studenten dit ervaren. Gegevens uit de programmaevaluatie en een aantal aanvullende vragen met betrekking tot het derde Engelstalige blok zijn geanalyseerd.

Resultaten: Het blijkt dat een ruime meerderheid van de studenten aangeeft in de onderwijsgroep Engels te spreken. Dit percentage neemt af in de loop van de drie blokken. Er wordt vaker Engels gesproken als er een buitenlandse student in de onderwijsgroep zit. Het merendeel van de studenten is van mening dat de tutoren het Engels in voldoende mate beheersen. Verder is $70 \%$ van de studenten voorstander van Engelstalig onderwijs. De helft van de studenten vindt dat dit de discussies in de onderwijsgroep negatief beïvloedt. Als er een keuzemogelijkheid zou zijn in het derde blok, kiest ongeveer $40 \%$ voor een Engelstalige onderwijsgroep in dit blok.

Discussie: De meerderheid van de studenten is voorstander van het oefenen van Engels. Twee blokken wordt door de meerderheid genoeg gevonden. Inmiddels kunnen de studenten in het derde blok kiezen voor Engels- of Nederlandstalig onderwijs. De aanwezigheid van een buitenlandse student heeft invloed op het Engels spreken. Bij de indeling in onderwijsgroepen moet daar dus rekening mee gehouden worden. (Dijcks R, Dolmans DHJM, Glatz $J F C$. Het gebruik van Engels als voertaal in het medisch onderwijs. Tijdschrift voor Medisch Onderwijs 2001;20(4): 134-139.)

\section{Inleiding}

Sinds 1993 wordt in het vierde jaar van de studie geneeskunde aan de Universiteit Maastricht een deel van het onderwijs (drie blokken) aangeboden in de Engelse taal. Een onderwijsblok duurt zes weken. Hierin staat een thema centraal. Per week zijn er twee bijeenkomsten van de onderwijsgroepen (tien studenten met tutor) en per blok enkele lezingen voor de hele jaargroep. Het aantal studenten bedraagt per studiejaar ongeveer 200, wat neerkomt op ongeveer twintig onderwijsgroepen. Elk blok wordt afgesloten met een kennistoets bestaande uit juist/onjuist-vragen. Het Engelstalige onderwijs vindt plaats tijdens het tweede, derde en vierde blok in het vierde jaar: blok 4.2 (Abdominal Complaints), blok 4.3 (Blood Loss) en blok 4.4 (Fatigue and Weight Loss). In totaal is er dus een periode van achttien weken waarin het Engels de voertaal is van de discussies in de onderwijsgroepen en de lezingen. Tijdens deze periode nemen ook buitenlandse studenten deel aan het Engelstalige onderwijs. Voorafgaand aan de Engelstalige blokken kunnen studenten vrijblijvend en zonder kosten een cursus Medisch Engelse Taalvaardigheid volgen. Ook voor docenten bestaat een dergelijke regeling. Overigens vindt de afsluitende toets voor de Nederlandse studenten in het 
Nederlands plaats en wordt de toets voor buitenlandse studenten in het Engels vertaald. Deze regeling is ingevoerd omdat men volgens het examenreglement verplicht is Nederlandstalige toetsen aan te bieden.

Het gebruik van Engels als voertaal in een gedeelte van een Nederlands geneeskundecurriculum is niet eerder beschreven. De argumenten om Engelstalig onderwijs in te voeren passen binnen de internationaliseringsdoelstellingen van de Universiteit Maastricht. Een van deze doelstellingen is dat artsen ten minste het Engels als vreemde taal dienen machtig te zijn, inclusief het Angelsaksisch medisch jargon. ${ }^{1}$ Ook biedt Engelstalig onderwijs de mogelijkheid om buitenlandse studenten te laten deelnemen aan het reguliere onderwijs. De aanwezigheid van buitenlandse gasten in de instelling draagt ertoe bij dat buitenlandse en Nederlandse studenten onderling contacten leggen en met elkaar integreren. ${ }^{2}$ Andere redenen om Engels te spreken tijdens het onderwijs zijn dat Engels een zeer belangrijke internationale taal in de medische communicatie is en dat onze samenleving multicultureel is, waardoor ook steeds meer met patiënten in het Engels wordt gecommuniceerd.

Vanaf de invoering van de Engelse blokken in 1993 is er systematisch geëvalueerd hoe de studenten deze vorm van onderwijs ervaren. Uit deze evaluaties kwamen signalen van studenten dat het gebruik van Engels een nadelige invloed zou hebben op de kwaliteit van de discussie in de onderwijsgroep. Studenten willen in de onderwijsgroep vooral discussiëren over onderdelen van de leerstof die niet helemaal helder zijn, en vinden het moeilijk om in het Engels problemen te verduidelijken en aan andere studenten uitleg te geven. Ook gaf men aan dat het zonder een buitenlandse student in de onderwijsgroep moeilijk was om Engels te praten.
In het Onderwijs Overleg Geneeskunde (het dagelijks bestuur van het Onderwijsinstituut Geneeskunde) besloot men naar aanleiding hiervan een gericht vervolgonderzoek in te stellen om de vraag te beantwoorden of studenten Engelstalig onderwijs wel wenselijk vinden, ook als ze ervaren dat dit een negatief effect heeft op de kwaliteit van de discussie in de onderwijsgroep. Ook werd onderzocht hoeveel blokken de studenten in de Engelse taal zouden willen volgen.

In dit artikel worden de resultaten besproken van evaluatiegegevens van alle Engelstalige blokken in drie opeenvolgende academiejaren en van het gerichte vervolgonderzoek bij vierdejaars studenten in blok 4.4 van het academisch jaar $1998 / 1999$. Nagegaan is in hoeverre in de onderwijsgroep Engels wordt gesproken en wat de wensen van de studenten zijn.

\section{Methode}

In de academische jaren 1996/1997, 1997/1998 en 1998/1999 werden na afloop van elk van de Engelstalige blokken vier stellingen voorgelegd aan de studenten (evaluatieonderzoek). Dit evaluatieonderzoek werd uitgevoerd bij de bloktoets, tezamen met de afname van de reguliere evaluatielijst.

De volgende stellingen werden aan de studenten voorgelegd:

1. In de onderwijsgroep werd vrijwel altijd Engels gesproken.

2. De tutor beheerste het Engels in voldoende mate.

3. Het gebruik van de Engelse taal heeft volgens mij een negatief effect op de kwaliteit van de discussie.

4. Ik ben een voorstander van het oefenen van 'medisch Engels' in de onderwijsgroepen. 
In 1998/1999 werden aan het eind van blok 4.4 voor het vervolgonderzoek drie extra stellingen aan de studenten voorgelegd:

5. Indien er een keuze zou zijn tussen Engelstalige en Nederlandstalige onderwijsgroepen, zou ik voor een Engelstalige onderwijsgroep kiezen.

6. Ik vind twee Engelstalige blokken voldoende (momenteel zijn er drie).

7. Ik ben een voorstander van een keuzemogelijkheid voor een Engelstalige of Nederlandstalige bloktoets.

De studenten konden steeds op een vijfpuntsschaal aangeven in welke mate ze het eens waren met een stelling ( 1 = helemaal oneens; 5 = helemaal eens).

Om na te gaan of de aanwezigheid van een buitenlandse student in de onderwijsgroep invloed had op de mate waarin Engels werd gesproken, is bij het analyseren van de resultaten onderscheid gemaakt tussen studenten die een buitenlandse student in de groep hadden en zij die dit niet hadden. Het totaal aantal buitenlandse studenten varieerde per jaar en per blok. In blok 4.2 en 4.3 varieerde dit aantal tussen 22 en 39 , wat neerkomt op gemiddeld 1 á 2 studenten per onderwijsgroep. In blok 4.4 waren er de afgelopen academische jaren tussen 9 en 20 buitenlandse studenten aanwezig, wat neerkomt op geen of 1 student per onderwijsgroep.

De respons op elk van de evaluaties was meer dan 90\%. Voor de rapportage zijn de uiterste waarden van de vijfpuntsschaal samengevoegd, resulterend in drie categorieën: eens, neutraal of oneens. De resultaten zijn op studentniveau per blok geanalyseerd. Aangezien er nauwelijks verschillen bleken te zijn tussen de drie academiejaren, is besloten de resultaten samen te voegen.

\section{Resultaten}

De meerderheid van de studenten is het eens met de stelling dat er vrijwel altijd Engels wordt gesproken in de onderwijsgroep. Opvallend is dat er sprake is van een afname van Engels spreken in de loop van de drie blokken van $96 \%$ tot $69 \%$ (tabel 1). Indien gekeken wordt naar de verschillen tussen onderwijsgroepen met en zonder buitenlander, blijkt dat in onderwijsgroepen waar een buitenlandse student aanwezig is, vaker (97\%) Engels wordt gesproken dan in onderwijsgroepen zonder buitenlandse student (57\%). Om na te gaan in welke mate de tutoren de Engelse taal beheersen, is studenten gevraagd om aan te geven of de tutor goed Engels sprak. De resultaten laten zien dat weinig studenten (4-8\%) vinden dat de tutor het Engels in onvoldoende mate beheerst. De derde stelling was bedoeld om te onderzoeken hoe studenten de invloed van het Engels spreken op de kwaliteit van de discussie in de onderwijsgroep beoordelen. Ongeveer de helft van de studenten (46-53\%) beweert dat het Engelstalig onderwijs een negatief effect heeft op de kwaliteit van de discussie in de onderwijsgroep. Wat betreft de voorkeur van studenten blijkt dat een grote groep (circa $70 \%$ ) voorstander is van het oefenen van 'medisch Engels' in de onderwijsgroepen.

Over de wensen ten aanzien van Engelstalig onderwijs blijken de studenten nogal van mening te verschillen. Indien er een keuze zou zijn tussen een Engelstalige en een Nederlandstalige onderwijsgroep zou een minderheid (41\%) kiezen voor een Engelstalige groep. Een meerderheid van de studenten $(61 \%)$ vindt twee Engelstalige blokken voldoende. Verder is bijna de helft van de studenten (45\%) voorstander van een keuzemogelijkheid tussen een Engelstalige en een Nederlandstalige bloktoets. 
Tabel 1. Percentage studenten dat op een vijfpuntsschaal een score eens $(>3)$, neutraal $(=3)$ of oneens $(<3)$ heeft toegekend. De resultaten van stelling 1 tot en met 4 worden weergegeven voor blok $4.2\left(\mathrm{~N}=515^{*}\right)$, $4.3\left(N=488^{*}\right)$ en $4.4\left(N=487^{*}\right)$ in drie academiejaren (1996-1999). Stelling 5, 6 en 7 zijn voorgelegd aan het eind van blok 4.4 in 1998/1999 ( $N=171)$.

\begin{tabular}{lllll}
\hline & & \multicolumn{3}{c}{ Resultaten } \\
\cline { 3 - 5 } Stelling & & eens & neutraal & oneens \\
\hline
\end{tabular}

1. In de onderwijsgroep werd vrijwel altijd Engels gesproken.

$\begin{array}{llll}4.2 & 96 & 1 & 3 \\ 4.3 & 85 & 4 & 11 \\ 4.4 & 69 & 4 & 27 \\ & & & \\ 4.2 & 87 & 5 & 8 \\ 4.3 & 86 & 10 & 4 \\ 4.4 & 78 & 17 & 5\end{array}$

3. Het gebruik van de Engelse taal heeft volgens mij een negatief effect op de kwaliteit van de discussie.

$\begin{array}{llll}4.2 & 46 & 19 & 35 \\ 4.3 & 50 & 16 & 34 \\ 4.4 & 53 & 17 & 30\end{array}$

4. Ik ben een voorstander van het oefenen van 'medisch Engels' in de onderwijsgroepen.

$\begin{array}{llll}4.2 & 70 & 16 & 14 \\ 4.3 & 71 & 15 & 14 \\ 4.4 & 68 & 15 & 17\end{array}$

5. Indien er een keuze zou zijn tussen Engelstalige en Nederlandstalige onderwijsgroepen, zou ik een Engelstalige onderwijsgroep kiezen.

6. Ik vind twee Engelstalige blokken voldoende (momenteel zijn er drie).

7. Ik ben voorstander van een keuzemogelijkheid voor een Engelstalige of Nederlandstalige bloktoets.

${ }^{*} N=$ aantal studenten van de drie opeenvolgende academiejaren samen.

\section{Discussie}

Het doel van dit onderzoek was allereerst na te gaan of gedurende de Engelstalige blokken in de onderwijsgroepen Engels wordt gesproken. De resultaten laten zien dat dit in de meerderheid van de onderwijsgroepen het geval is. Ook blijkt het merendeel van de studenten die deelnamen aan het onderzoek van mening te zijn dat de tutoren het Engels in voldoende mate beheersen. Opvallend is dat er sprake is van een afname van Engels spreken in de loop van de Engelstalige periode. Een mogelijke verklaring hiervoor is dat er tegen het einde van de betreffende periode minder buitenlandse studenten aanwezig zijn, waardoor niet meer in elke onderwijsgroep ten minste één buitenlandse student aanwezig kan zijn. De aanwezigheid van een buitenlandse student in de onderwijsgroep blijkt namelijk een belangrijke drijfveer om Engels te spreken. Dat deze verklaring aannemelijk is, blijkt ook uit de bevinding 
dat er, wat betreft de mate waarin Engels gesproken wordt in de groep, een groot verschil bestaat tussen groepen met en groepen zonder een buitenlandse student. Dit impliceert dat - indien men streeft naar Engelstalige onderwijsgroepen men moet trachten om aan elke onderwijsgroep ten minste één buitenlandse student te laten deelnemen.

Een punt van zorg is de invloed van Engels op de kwaliteit van de discussie in de onderwijsgroep. Bijna de helft van de studenten vindt dat het gebruik van Engels een negatief effect heeft op de kwaliteit van de groepsdiscussie. Het verdient aanbeveling om te onderzoeken of studenten die de cursus Medisch Engelse Taalvaardigheid gevolgd hebben, minder moeite hebben met Engels spreken tijdens de onderwijsgroep en of zij het negatieve effect minder sterk percipiëren. Wellicht zijn er mogelijkheden om de kwaliteit van de groepsdiscussie via deze voorbereidende cursus te verbeteren. Daarbij kan overwogen worden een ingangstoets af te nemen en een grenswaarde te definiëren waaronder deelname aan de cursus verplicht wordt gesteld.

In dit onderzoek is ook onderzocht welke voorkeuren studenten hebben ten aanzien van Engelstalig onderwijs. Het blijkt dat circa $70 \%$ van de studenten voorstander is van het oefenen van 'medisch Engels'. Opvallend is de discrepantie tussen dit laatste gegeven en het eerder beschreven gegeven dat $50 \%$ van de studenten vindt dat Engels onderwijs een negatief effect heeft op de kwaliteit van de discussie. Het is onduidelijk hoe deze discrepantie geïnterpreteerd moet worden. Als er een keuzemogelijkheid zou zijn voor het laatste blok, zou $41 \%$ voor een Engelse groep kiezen.

Bij de resultaten van dit onderzoek moeten enkele kanttekeningen worden geplaatst. In dit onderzoek is alleen de mening van de studenten gevraagd over hoe zij het gebruik van de Engelse taal ervaren. Het is evenwel zinvol om ook de mening van docenten vast te stellen. Het is de vraag of ook zij vinden dat de kwaliteit van de groepsdiscussie negatief wordt beïnvloed door het gebruik van de Engelse taal. Verder is in dit onderzoek volstaan met het voorleggen van stellingen aan studenten. Om meer inzicht te krijgen in de motieven van studenten zou een andere onderzoeksmethode, bijvoorbeeld het afnemen van interviews, geschikt zijn. Ten slotte lijkt het zinvol te onderzoeken of de uiteindelijke doelstellingen van het gebruik van Engels als voertaal in het medisch onderwijs worden gehaald, met name of de spreekvaardigheid in Engels daardoor toeneemt en of er echt sprake is van integratie tussen Nederlandse en buitenlandse studenten.

Gegeven deze resultaten en de bevinding dat in het laatste blok minder buitenlandse studenten participeren, zijn met ingang van het jaar 1999/2000 twee Engelstalige blokken verplicht gesteld en wordt bij het derde blok een keuzemogelijkheid aangeboden voor een Nederlandstalige of een Engelstalige onderwijsgroep. Dit komt ook tegemoet aan de 30\% die geen voorstander is van Engelstalig onderwijs.

\section{Literatuur}

1. Majoor GD, Willemstein SC. Internationalisering van het medisch onderwijs. Ned Tijdschr Geneeskd 1996;140(2):100-2.

2. Majoor GD. Internationalisering van curricula voor het gezondheidszorgonderwijs. In: Houtkoop E, Pols J, Pollemans MC, Scherpbier AJJA, Verwijnen GM, redactie. Gezond Onderwijs 3. 's-Gravenhage: Haagse Hogeschool; 1994. p. 273-275.

De auteurs:

R. Dijcks is student geneeskunde en als student-assistent verbonden aan het Skillslab. Gedurende het onderzoek was hij lid van het Onderwijs Overleg Geneeskunde (Onderwijsinstituut). 
Dr. D.H.J.M. Dolmans is als onderwijskundige verbonden aan de Capaciteitsgroep Onderwijsontwikkeling en Onderwijsresearch.

Dr. J.F.C. Glatz is als fysioloog verbonden aan de Capaciteitsgroep Fysiologie en was gedurende het onderzoek voorzitter van de Opleidingscommissie.

Allen zijn verbonden aan de Faculteit der Geneeskunde van de Universiteit Maastricht.
Correspondentieadres:

D. Dolmans, Capaciteitsgroep Onderwijsontwikkeling en-Research, Universiteit Maastricht, Postbus 616, 6200 MD Maastricht.D.Dolmans@educ.unimaas.nl.

\section{Summary}

Introduction: In year four of the undergraduate curriculum of Maastricht Medical School there are three Englishlanguage blocks. The aim is to offer Dutch students an opportunity for practising 'medical English' and to enable the participation of students from abroad.

Method: Since their introduction the English-language blocks have been evaluated systematically. Data from the programme evaluation and supplementary questions relating to the third of the English-language blocks have been analysed.

Results: A large majority of students appears to speak English during tutorial group sessions. This percentage decreases over the course of the three blocks. The presence of a student from abroad in the group stimulates the usage of English. The majority of students considers the tutors' command of English to be satisfactory. Generally, students are in favour of English-language blocks. Half of the students think that the quality of the discussions in the tutorial group is affected negatively when they speak English. If students could choose between Dutch and English tutorial groups in the third block, some $40 \%$ would prefer an English-language block.

Discussion: The majority of students is in favour of the opportunity for practising their English. Two English blocks is considered sufficient by the majority. Currently, students can choose between a Dutch or English third block in year four. The presence of a student from abroad in the group stimulates the use of English. This should be taken into account when the groups are constituted. (Dijcks R, Dolmans DHJM, Glatz JFC. English as the language of medical education. Dutch Journal of Medical Education 2001;220(4): 134-139.) 